\title{
Timing of forage fish seasonal appearance in the Columbia River plume and link to ocean conditions
}

\author{
Amanda M. Kaltenberg ${ }^{1, *}$, Robert L. Emmett ${ }^{2}$, Kelly J. Benoit-Bird ${ }^{1}$ \\ ${ }^{1}$ College of Oceanic and Atmospheric Sciences, Oregon State University, 104 COAS Admin. Bldg. Corvallis, Oregon 97331, USA \\ ${ }^{2}$ Northwest Fisheries Science Center, NOAA, Hatfield Marine Science Center, 2032 SE OSU Dr., Newport, Oregon 97365, USA
}

\begin{abstract}
This study described the phenology and patterns of variability of forage fish and mesozooplankton populations near the Columbia River plume. Our objective was to identify the timing of the seasonal appearance of forage fish and to characterize the temporal patterns of abundance in relation to ocean conditions including zooplankton availability. Observations were collected at 2 stations in 2008 and 2009 using $200 \mathrm{kHz}$ bio-acoustic moorings, and with bi-weekly net sampling surveys conducted at nearby stations to measure total fish density and relative species composition. Acoustic time series results revealed that the seasonal timing of acoustic schools, representing the forage fishes northern anchovy Engraulis mordax, whitebait smelt Allosmerus elongatus, and Pacific sardine Sardinops sagax, occurred abruptly, with specific dates of appearance identified at each station in mid-May in both years. Both 2008 and 2009 represented very similar years for the timing and strength of wind-driven coastal upwelling. The timing of forage fish appearances in these years was linked with ocean temperature and salinity data collected at a nearby oceanographic buoy but was poorly correlated with mesozooplankton abundance, which was highly variable and fluctuating over a period of hours to days. Fluctuations in zooplankton and forage fish populations drive many trophic interactions, including juvenile salmon, seabirds, and large predators (e.g. adult salmon) that rely on the timing and abundances of these populations and have significant implications for ecosystem based management.
\end{abstract}

KEY WORDS: Forage fish · Zooplankton · Acoustics · Phenology · Upwelling · Columbia River plume $\cdot$ California Current $\cdot$ Sardines $\cdot$ Anchovies

\section{INTRODUCTION}

Fish communities in coastal upwelling regions of the world are generally dominated by a few species of very abundant small schooling forage fish (Cury et al. 2000). These forage fishes, including sardines, anchovies, herring, and smelts, are generalist plankton grazers that opportunistically feed on phytoplankton, copepods, or euphausiids, (Brodeur \& Pearcy 1992, Robinson 2000, Emmett et al. 2005) and are significant consumers of primary and secondary production (Lasker 1970, Emmett et al. 2005). Forage fish are an important prey resource in these ecosystems, supporting a variety of predators including larger fish, marine mammals, and seabirds, and serve as a critical link between plankton resources and upper trophic levels. In the northern California Current upwelling system, the abundance of forage fishes varies with season. Pacific sardine Sardinops sagax typically appear on the Oregon and Washington coasts in May, peak in August, and are absent by the end of October, while the peak in northern anchovy Engraulis mordax catches typically occurs earlier (May or June) and closer to shore than sardines (Emmett et al. 2006).

The abundance and timing of forage fish populations in the coastal region play a significant role in a number of ecosystem interactions, including the timing and success of seabird breeding performance (Anderson et al. 1982, Safina \& Burger 1988, Hedd et al. 2006, Anderson et al. 2007), and the ecology of sea lions 
(Sinclair \& Zeppelin 2002, Womble et al. 2005, Weise et al. 2006, Womble \& Sigler 2006), killer whales (Similä et al. 1996), and minke whales (Macleod et al. 2004). The timing of forage fish presence is also hypothesized to be an important factor in determining juvenile salmon marine survival by providing alternative prey for large piscivorous fish, marine mammals, and seabirds (Pearcy 1992). There is a trend for juvenile salmon survival to be high when forage fish populations are high, and in years when sardine and anchovy populations have been low, salmon survival has been low (Emmett \& Sampson 2007). Therefore, the temporal and spatial dynamics of forage fish may be critical variables determining these ecosystem interactions.

The Columbia River plume region adjacent to the Washington-Oregon border is an important transition area for a large number of juvenile salmon of the west coast of the United States and provides habitat for many commercially important species (salmon, sardines, Dungeness crab Cancer magister, albacore tuna Thunnus alalunga, etc). Oceanographic conditions in this area are strongly influenced by the interaction of Columbia River flows, winds, and tides, and there is often a bi-directional surface plume of fresh river water (Hickey et al. 2005). This plume may extend up to $400 \mathrm{~km}$ offshore and along the entire Washington and Oregon coast. Upwelling conditions facilitate the offshore and southward transport of the river plume, whereas downwelling conditions push the plume northward and tight to the coast.

The distribution of mesozooplankton, an important prey item of forage fish, appears to be driven by these ocean conditions and wind patterns in the Columbia River plume, creating a retention mechanism for vertically migrating coastal zooplankton (Peterson 1998, Lamb \& Peterson 2005). Sardine and anchovy schools are highly mobile and can quickly respond to changing local conditions to select their preferred habitat. However, zooplankton are much less mobile, and increased abundances have been associated at convergence zones with strong gradients in density and current velocity (Morgan et al. 2005, Woodson et al. 2005). Increased zooplankton biovolume has been observed at the Columbia River front and at depths near the base of the plume (Peterson \& Peterson 2008), which may provide a mechanism for the cross-shelf transport of zooplankton (Peterson \& Peterson 2009).

Surface trawl surveys from this region indicate that the pelagic fish community is typically dominated by Pacific sardine Sardinops sagax, northern anchovy Engraulis mordax, Pacific herring Clupea pallasi, and whitebait smelt Allosmerus elongatus (Brodeur et al. 2003). These species are obligate schooling fish, meaning they spend most of their lives in coherently organized schools (Breder 1976). These schools typically exhibit strong diel behavior with discrete schools present during daytime, which disperse horizontally and vertically throughout the water column at night (Azzali et al. 1985, Fréon et al. 1996, Fréon \& Misund 1999, Cardinale et al. 2003, Kaltenberg \& Benoit-Bird 2009).

The abundances of all forage species have high levels of interannual variability, particularly sardines and anchovies (Baumgartner et al. 1992, Hsieh et al. 2006). However, oceanographic mechanisms driving this high natural variability are poorly understood. Variability of forage fish populations has been linked to decadal-scale oscillations of atmospheric forcing (Lluch-Belda et al. 1992), interannual patterns of wind stress curl (Rykaczewski \& Checkley 2008), and ocean conditions (Brodeur et al. 2005). However, little information is available to examine the effects of more localized and frequent sources of variability such as upwelling events and riverine influences on forage fish abundance. Local patterns of population variability likely determine the degree of spatial and temporal overlap between the forage fish population and other ecosystem groups that rely on them as either prey (e.g. adult salmon, marine mammals, and seabirds) or as alternative prey to mutual predators (e.g. juvenile salmon).

The objective of this study was to characterize the local patterns of variability and abundance of schooling forage fish near the mouth of the Columbia River to determine how oceanographic variables influence their seasonal timing of appearance to the Columbia River plume region.

\section{MATERIALS AND METHODS}

Bio-acoustic moorings. Bio-acoustic moorings were deployed at 2 stations near the mouth of the Columbia River to collect acoustic abundance time series data (Fig. 1): an inshore station $11 \mathrm{~km}$ from shore at $40 \mathrm{~m}$ water depth $\left(46.17^{\circ} \mathrm{N}, 124.12^{\circ} \mathrm{W}\right)$, and an offshore station $24 \mathrm{~km}$ from shore at $95 \mathrm{~m}$ depth $\left(46.04^{\circ} \mathrm{N}\right.$, $124.25^{\circ} \mathrm{W}$ ). These specific stations were selected because they are within the typical forage fish habitat and they were adjacent to 2 OGI (Oregon Graduate Institute) oceanographic buoys maintained by Clastsop Community College, Astoria, OR. These buoys provided surface expressions of the equipment as a deterrence to trawl fishermen, and reduced the chances of instrument interference. The acoustic moorings were placed on the seafloor just outside of the swing radius of the surface OGI buoys to prevent contamination of the acoustic data. Previous sampling utilizing these moorings has shown that there is a high correlation among moorings placed in the corners of a $1 \mathrm{n}$ mile $(1.85 \mathrm{~km})$ square box pattern, indicating that one 


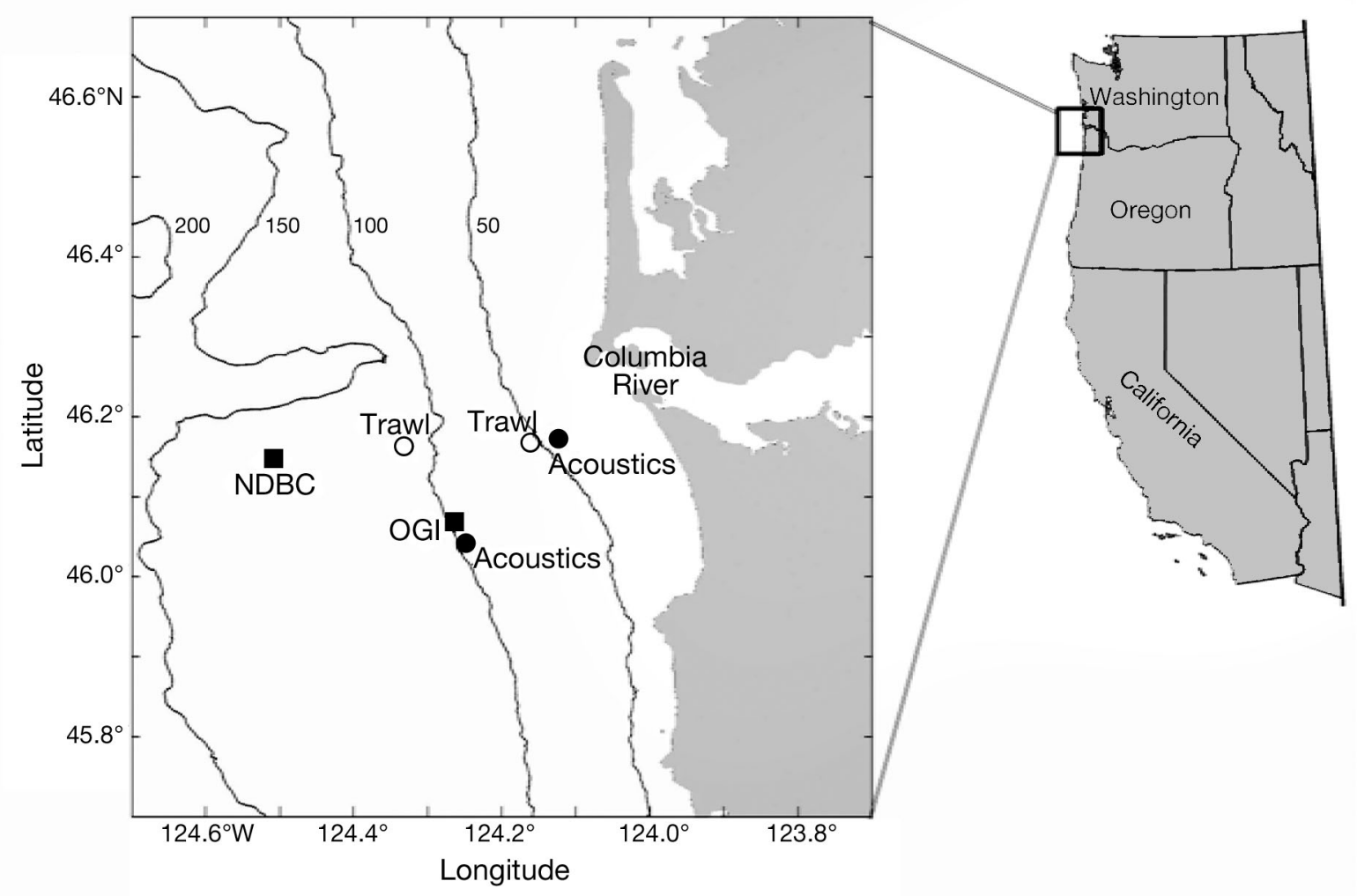

Fig. 1. Study area and sampling stations with the 50,100, 150, and $200 \mathrm{~m}$ isobaths. The National Data Buoy Center buoy (NDBC $\square$ ) is $37 \mathrm{~km}$ from shore. An Oregon Graduate Institute buoy (OGI $\mathbf{\square}$ ) is located at the deep acoustic mooring station (20 $\mathrm{n}$ mile). The 2 bottom-mounted acoustic moorings $(\bullet)$ are 11 and $24 \mathrm{~km}$; the trawl sampling stations (O) are 13 and $28 \mathrm{~km}$ from shore

mooring station provides daily abundance data representative of sampling over a spatial scale of at least $1 \mathrm{n}$ mile $^{2}$ (Kaltenberg \& Benoit-Bird 2009).

Sampling took place from March 31 to June 27, 2008, and from April 10 to June 21, 2009 using moored, upward-looking, $200 \mathrm{kHz}$ echosounders (Water Column Profiler, ASL Environmental Science, Sydney, BC, Canada; $3 \mathrm{~dB}$ beamwidth of $10^{\circ}$ sampling with a transmitted pulse length of $156 \mu \mathrm{s})$. In 2008, moorings were set to sample with a vertical resolution of $0.5 \mathrm{~m}$ with a pulse rate of $0.125 \mathrm{~s}^{-1}$ and recorded on an internally stored drive. In 2009 when data were recorded to replaceable compact flash cards with a larger storage capacity, the vertical resolution was increased to $0.25 \mathrm{~m}$ with a pulse rate of $1 \mathrm{~s}^{-1}$. In 2008, the moorings were replaced once midstudy on May 14, however the mooring at the shallow site was not recovered (i.e. was missing). In 2009, one set of moorings were used throughout the entire sampling period.

The acoustic mooring instruments were deployed from the MV Forerunner by lowering the instrument attached to sandbag anchors to the seafloor before releasing the deployment wire with an acoustic release. The upward pointing transducer was posi- tioned $1 \mathrm{~m}$ above the seafloor and orientated upward using sandbag anchors. Floats were attached to each instrument below the transducer to keep the instrument stable. This stability was confirmed using an internal logging tilt and roll sensor in each instrument. No floats or lines were placed above the instrument package to prevent unintended acoustic returns or fish aggregations near the instruments. The design of the instrument package has been previously tested during prior sampling on the Oregon coast, and is further described in Kaltenberg \& Benoit-Bird (2009). The moorings were recovered at the end of the sampling period in both years by the FV Piky using an acoustic release that allowed the instrument package to float to the surface, sacrificing the sandbag anchors.

Physical oceanography. The oceanographic habitat was characterized using data from one oceanographic buoy operated by OGI, which was located at the deep acoustic mooring station (Fig. 1). This buoy measured sea surface temperature and sea surface salinity data from $0.8 \mathrm{~m}$ below the surface once every $5 \mathrm{~min}$ in 2008 and once every $15 \mathrm{~min}$ in 2009. A $24 \mathrm{~h}$ running average filter was applied to the oceanographic data to remove diurnal variability. 
Columbia River flow (daily discharge volume data) was collected at Beaver Army Terminal, near Quincy, Oregon, (located $86.6 \mathrm{~km}$ upstream from the river mouth) by the United States Geological Service (available at http://waterdata.usgs.gov/nwis). This site represents $\sim 97 \%$ of the total river flow at the Columbia River mouth during summer conditions (Bottom et al. 2001).

Daily upwelling indices were obtained from NOAA's Pacific Fisheries Environmental Laboratory, Environmental Research Division, which are based on estimates of offshore Ekman transport driven by geostrophic wind stress (Bakun 1973). Values were derived from mean atmospheric pressure field at $45^{\circ} \mathrm{N}$, $125^{\circ} \mathrm{W}$ (available at www.pfeg.noaa.gov). The date of the spring transition was determined using the cumulative upwelling method, which is defined as the date of minimum cumulative upwelling from the beginning of the year after a 10 d running average filter was applied to the daily upwelling index values (Schwing et al. 1996). The spring transition marks the timing of a shift in coastal oceanographic conditions from predominantly downwelling in the winter to predominately upwelling in the summer. This method has been commonly used to characterize the spring transition and is appropriate for the northern California Current where there is a relatively large contrast between winter and summer wind conditions (Bograd et al. 2009, Holt \& Mantua 2009).

Fish sampling. The pelagic fish community was sampled during a series of research cruises that took place as part of the ongoing NOAA Predator Study (Emmett et al. 2006). Trawl data from the 2 stations nearest the moorings were used for total fish density and relative species composition. Stations at 13 (CR7) and 28 (CR15) $\mathrm{km}$ from the mouth of the Columbia River were sampled from the FV Piky (Fig. 1). The trawl station CR7 was located $2.4 \mathrm{~km}$ from the shallow acoustic mooring station at a depth of $60 \mathrm{~m}$, and trawl station CR15 was located $15.2 \mathrm{~km}$ from the deep mooring sta- tion at a depth of $120 \mathrm{~m}$. Sampling took place approximately once every 2 weeks in May and June in both years. Trawls were conducted using a Nordic 264 rope trawl (30 m wide by $20 \mathrm{~m}$ high) with $3 \mathrm{~m}$ foam-filled lite doors towed astern of the vessel at $\sim 1.8 \mathrm{~m} \mathrm{~s}^{-1}$ (3.5 knots). Trawls were conducted at night, when schools are typically near the surface and dispersed. Nighttime samples also minimize net avoidance behaviors (Fréon \& Misund 1999). Density estimates were calculated for each species based on the area swept by the net. The relative acoustic indices at the mooring stations were visually compared with the total fish densities for each trawl conducted at Stns CR7 and CR15.

Analysis of bio-acoustic data. Bio-acoustic mooring data were converted from echo intensity into volume backscattering strength $\left(\mathrm{S}_{\mathrm{v}}, \mathrm{dB}\right.$ re $\left.1 \mathrm{~m}^{-1}\right)$ by the sonar equation (Urick 1983), using the manufacturer's calibrations before being analyzed using the acoustic processing software Echoview (Myriax). Minimum and maximum data thresholds of $-65 \mathrm{~dB}$ and $-30 \mathrm{~dB}$ were applied before the identification of acoustic features. Acoustical schools, defined as acoustically unresolved multiple fish or plankton aggregations (Kieser et al. 1993), were detected using the School Detection Module (Barange 1994) of Echoview combined with visual scrutiny (Kaltenberg \& Benoit-Bird 2009) as a proxy for forage fish abundance. Each aggregation was categorized into one of 5 categories based on visual characteristics: fish school, fish aggregation, fish layer, zooplankton aggregation, and zooplankton swarm (Fig. 2). Fish schools were distinct, rounded features (i.e. not layers), and relatively homogeneous within the region (in contrast to other aggregations).

Data from the 2009 moorings were used to compare the visually detected aggregation categories with a statistical detection method to test the robustness of visual identifications. The 2009 data were used for this test because the very high sampling resolution provided an opportunity to test the robustness of these categorizations. All aggregations (5 categories) were exported from

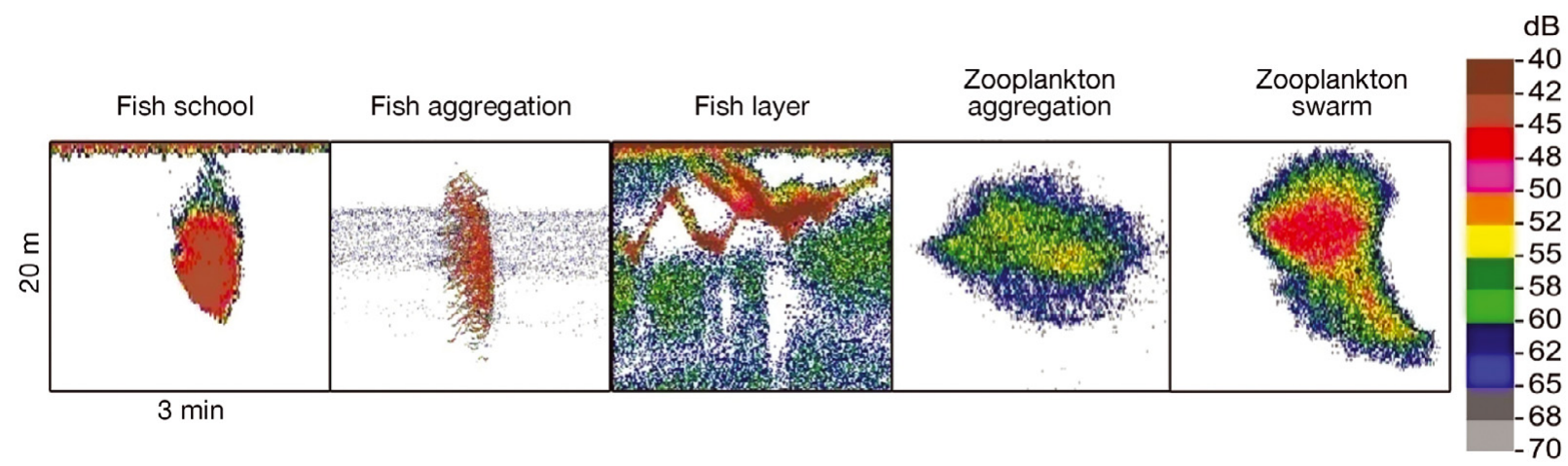

Fig. 2. Example echograms for each classification of aggregations detected visually and statistically. Each panel represents $20 \mathrm{~m}$ (vertical axis) recorded over 3 min duration (horizontal axis) with acoustic backscatter in decibel (dB) 
Echoview for analysis and the categories were statistically tested using a 2 step cluster analysis (using SPSS statistical software) with a fixed number of clusters set to 5. Fourteen aggregation descriptor variables (Table 1) were used to assign each aggregation to a cluster group. The statistically determined groupings were then compared with the visually determined groups. Only fish schools that were detected both visually and statistically were used for analysis of forage fish abundance (300 statistically detected schools out of 304 visually detected schools). The integrated nautical area scattering coefficient (NASC) for each school was binned into daily bins to obtain a daily index for forage fish abundance. This combined technique of visual scrutiny with a statistical classification provided confidence that the acoustic school aggregations were distinct from other aggregations, likely representing forage fish schools.

To quantify the availability of zooplankton as potential prey to surface-foraging fish, regions defined as fish schools or fish aggregations were subtracted from the total acoustic backscatter, leaving an index of abundance that was used as a proxy for mesozooplankton. This proxy represents a slight over-estimate due to large single fish and dispersed schooling fish at nighttime that were likely included in this index. However, these biases are likely small and constant over the diel cycle. Abundance index data were binned into daily values from the surface to a depth of $20 \mathrm{~m}$.

The daily indices for zooplankton backscatter and schooling fish abundances were tested for correlation with each other and with physical oceanographic conditions using the non-parametric Kendall's tau correlation test.

\section{RESULTS}

\section{Upwelling and river flow}

In both 2008 and 2009, winds became upwellingfavorable in March. In 2008, the spring transition occurred on March 27. The spring transition date was slightly earlier in 2009, occurring on March 23, and the strength of seasonal upwelling after the transition was slightly less in 2009 than was observed in 2008 (Fig. 3). These were typical dates for the spring transition compared to the spring transition date for the previous $5 \mathrm{yr}$, which ranged from March 15 in 2007 to May 23 in 2005 (Fig. 3).

Columbia River flows increased during the first half of each study year, with peaks observed at the end of May in both 2008 and 2009 (Fig. 4). River flows were lower in April 2008 than in 2009, but increased rapidly in May 2008.

\section{Fish schooling}

A cluster analysis of all categories of aggregations indicated that aggregations classified as fish schools were distinct from other aggregations based on their statistical parameters. These statistically determined schools were in very high agreement with the visual classifications $(98.6 \%$ of visual schools were also determined statistically). Acoustic schools detected in echograms, which were also consistent with those typically observed for forage fish, were observed primarily during the daytime and very close to the

Table 1. Summary of 5 aggregation categories determined by cluster analysis of 14 aggregation descriptors (mean \pm SD). Only school categories were included in the analysis of forage fish abundance

\begin{tabular}{|c|c|c|c|c|c|c|}
\hline Variable & Fish school & $\begin{array}{l}\text { Fish } \\
\text { aggregation }\end{array}$ & Fish layer & $\begin{array}{l}\text { Zooplankton } \\
\text { aggregation }\end{array}$ & $\begin{array}{l}\text { Zooplankton } \\
\text { swarm }\end{array}$ & Combined \\
\hline Number of observances & 300 & 300 & 47 & 737 & 233 & 1617 \\
\hline NASC $\left(m^{2} n m^{2} e^{-2}\right)$ & $4040 \pm 3010$ & $2170 \pm 1920$ & $7440 \pm 8950$ & $1740 \pm 1630$ & $3800 \pm 4850$ & $2710 \pm 3290$ \\
\hline Skewness & $0.24 \pm 0.96$ & $0.90 \pm 0.96$ & $1.76 \pm 2.03$ & $1.24 \pm 1.04$ & $2.48 \pm 2.29$ & $1.19 \pm 1.46$ \\
\hline Kurtosis & $-0.50 \pm 2.37$ & $0.67 \pm 3.61$ & $9.13 \pm 18.3$ & $1.94 \pm 4.44$ & $14.3 \pm 22.9$ & $3.24 \pm 11.0$ \\
\hline Corrected duration $^{\mathrm{a}}(\mathrm{s})$ & $152 \pm 103$ & $152 \pm 120$ & $1120 \pm 847$ & $138 \pm 90.7$ & $372 \pm 254$ & $205 \pm 264$ \\
\hline Corrected thickness (m) & $9.17 \pm 5.03$ & $5.62 \pm 3.60$ & $26.8 \pm 11.6$ & $5.84 \pm 3.29$ & $14.3 \pm 7.45$ & $8.25 \pm 6.58$ \\
\hline Corrected perimeter $^{\mathrm{a}}(\mathrm{m})$ & $460 \pm 319$ & $453 \pm 351$ & $4390 \pm 3040$ & $401 \pm 266$ & $1340 \pm 731$ & $672 \pm 965$ \\
\hline Corrected area ${ }^{\mathrm{a}}\left(\mathrm{m}^{2}\right)$ & $872 \pm 915$ & $486 \pm 552$ & $10900 \pm 6380$ & $464 \pm 430$ & $2350 \pm 1600$ & $1120 \pm 2260$ \\
\hline Image compactness ${ }^{\mathrm{a}}$ & $23.4 \pm 14.3$ & $44.8 \pm 39.7$ & $178 \pm 175$ & $34.6 \pm 25.4$ & $79.2 \pm 63.3$ & $45.0 \pm 53.8$ \\
\hline Coefficient of variation $(\%)$ & $92.5 \pm 33.6$ & $110 \pm 33.2$ & $125 \pm 53.0$ & $119 \pm 35.3$ & $151 \pm 70.7$ & $117 \pm 45.5$ \\
\hline $\begin{array}{l}\text { Horizontal roughness coefficient } \\
\left(10^{-6}\left[\mathrm{~dB} \text { re } 1 \mathrm{~m}^{2} \mathrm{~m}^{-3}\right]\right)\end{array}$ & $5.09 \pm 4.04$ & $11.0 \pm 8.23$ & $5.34 \pm 3.44$ & $12.0 \pm 12.2$ & $8.65 \pm 8.49$ & $9.84 \pm 10.0$ \\
\hline $\begin{array}{l}\text { Vertical roughness coefficient } \\
\left(10^{-6}\left[\mathrm{~dB} \text { re } 1 \mathrm{~m}^{2} \mathrm{~m}^{-3}\right]\right)\end{array}$ & $4.14 \pm 3.37$ & $23.0 \pm 23.1$ & $6.22 \pm 6.11$ & $17.5 \pm 20.0$ & $9.45 \pm 9.47$ & $14.6 \pm 18.4$ \\
\hline 3D school area ${ }^{a}\left(m^{2}\right)$ & $6180 \pm 6790$ & $4060 \pm 4760$ & $107000 \pm 96500$ & $3570 \pm 3450$ & $20400 \pm 14400$ & $9580 \pm 25100$ \\
\hline 3D school volume ${ }^{\mathrm{a}}\left(\mathrm{m}^{3}\right)$ & $5790 \pm 8780$ & $1780 \pm 3120$ & $121000 \pm 132000$ & $01760 \pm 2530$ & $16300 \pm 16500$ & $8070 \pm 31000$ \\
\hline Mean depth $(\mathrm{m})$ & $4.96 \pm 4.55$ & $20.2 \pm 14.5$ & $17.3 \pm 10.7$ & $17.5 \pm 13.0$ & $20.1 \pm 12.8$ & $16.0 \pm 13.3$ \\
\hline
\end{tabular}




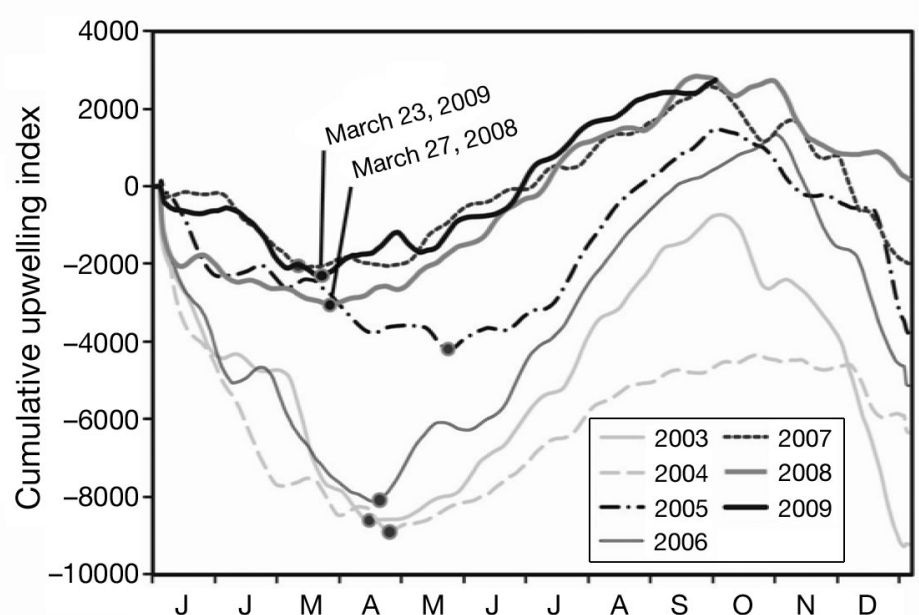

Fig. 3. Annual cumulative upwelling index at $45^{\circ} \mathrm{N}, 125^{\circ} \mathrm{W}$ for the period 2003 to 2009, from the Pacific Fisheries Environmental laboratory (www.pgeg.noaa.gov). Data were smoothed with a $10 \mathrm{~d}$ running average. Decreasing values = downwelling, increasing values = upwelling. (๑) Date of the spring transition for each year (date of minimum cumulative upwelling). The spring transition dates for 2008 and 2009 are indicated

surface $($ depth $=4.96 \pm 4.55 \mathrm{~m}$, all values are means \pm $\mathrm{SD}$, Table 1). Schools typically had lower skewness $(0.24 \pm 0.96)$ and kurtosis $(-0.50 \pm 2.37)$ values than other aggregations, indicating that they had higher internal homogeneity in density than other aggregations (Table 1). Schools also tended to have lower values for Image Compactness $(23.37 \pm 14.27)$, meaning that they were more rounded than other aggregations, and had a lower coefficient of variation (92.45 \pm 33.55), meaning that individuals are more evenly distributed within the school than in other aggregations (Table 1).

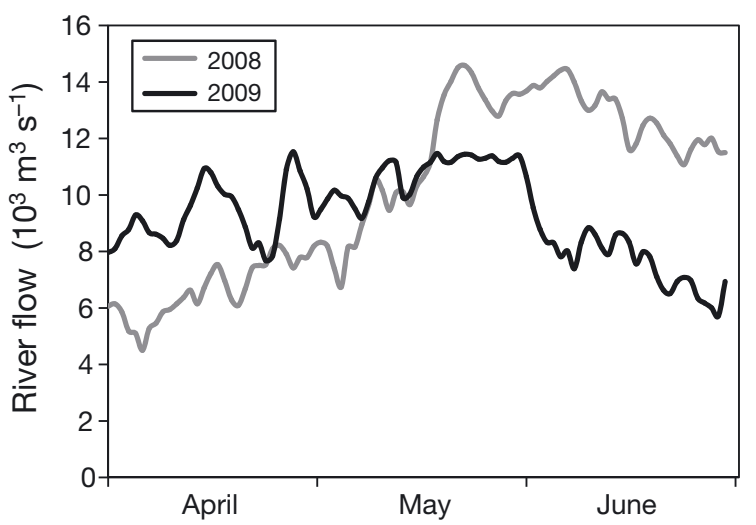

Fig. 4. Columbia River flow at Beaver Army Station, located $86.6 \mathrm{~km}$ upstream of the Columbia River mouth in 2008 and 2009. Peak flows in 2008 occurred on May 23, and several peak flows were observed in 2009, but the maximum peak occurred on May 8, 2009
Timing of schooling fish appearance

The continuous time series of schooling fish abundance from the 2 bio-acoustic mooring stations in 2008 and 2009 is shown in Fig. 5. Very few schools were detected in April and the first half of May at both mooring sites and in both years (note the shorter sampling period at the shallow station in 2008, beginning on May 14). One large spike in abundance was observed at the shallow station in 2008 just after the second deployment began (May 18), but it otherwise followed patterns similar to the other moorings with school abundance becoming high by the end of May and in June. The distinct timing for the appearance of schooling fish (when schools appeared and were consistently detected over multiple days) were pinpointed to specific dates: 24 May 2008 and 15 May 2009 at the deep station, and 17 May 2008 and 16 May 2009 at the shallow station (Fig. 5).

\section{Schooling fish and ocean conditions}

The daily acoustic indices indicated that there were generally much higher zooplankton abundances observed at the deep site (daily mean NASC $=4396 \mathrm{~m}^{2}$ $\mathrm{n}$ mile $^{-2}$ ) than the shallow site (daily mean NASC $=281$

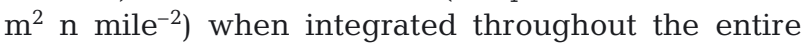
water column. However, since schooling fish were acoustically observed only within $20 \mathrm{~m}$ of the surface, zooplankton abundances were analyzed from the surface to $20 \mathrm{~m}$ depth (Fig. 6). No clear seasonal trends were visually observed for surface zooplankton abundance during the sampling period, but instead very large spikes were frequently observed, lasting from 1 to $3 \mathrm{~d}$ (Fig. 6).

A correlation test was conducted between schooling fish abundance and several variables of ocean conditions, including the acoustic proxy for zooplankton abundance for each station and each year (Table 2). The sampling year and station location had no significant correlation with schooling fish abundance. Very strong correlations were detected between schooling fish abundance and sea surface temperature and sea surface salinity, as well as schooling fish abundance and Columbia River flow. Schooling fish abundances were associated with high sea surface temperatures (Kendall's tau $=+0.36$ ), low sea surface salinity (Kendall's tau $=-1.6$ ), and high Columbia River flows (Kendall's tau $=+0.24$ ). In both 2008 and 2009, the timing of the arrival of schooling fish occurred when sea surface temperatures rose above $\sim 11^{\circ} \mathrm{C}$ (Fig. 7). Upwelling index and zooplankton abundance did not show a significant correlation with schooling fish abundance (Table 2). 

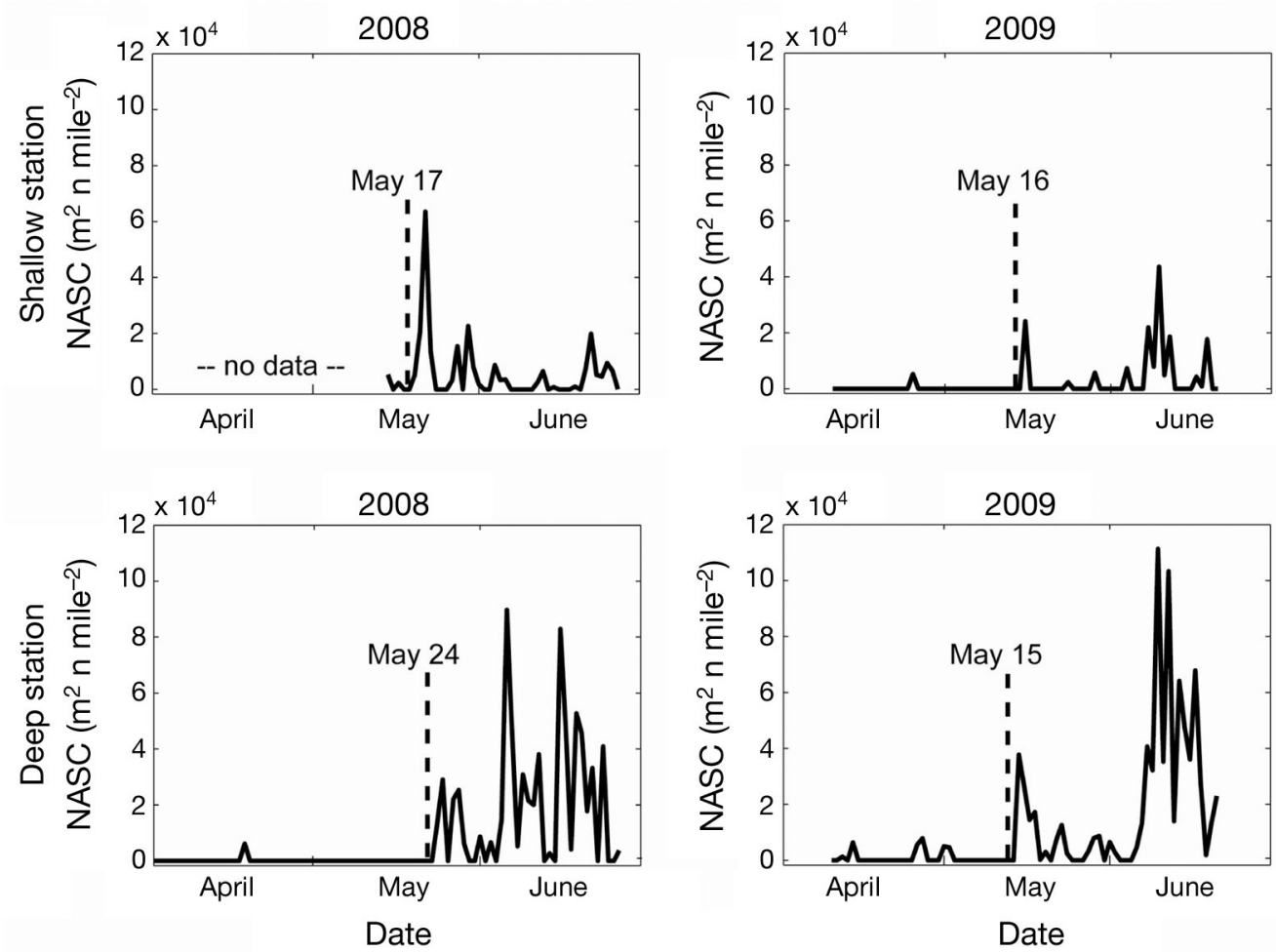

Fig. 5. Nautical area scattering coefficient, a proxy for forage fish abundance, for the shallow (top), and deep (bottom) mooring stations in 2008 and 2009. The dates of forage fish appearance are marked by the dashed line
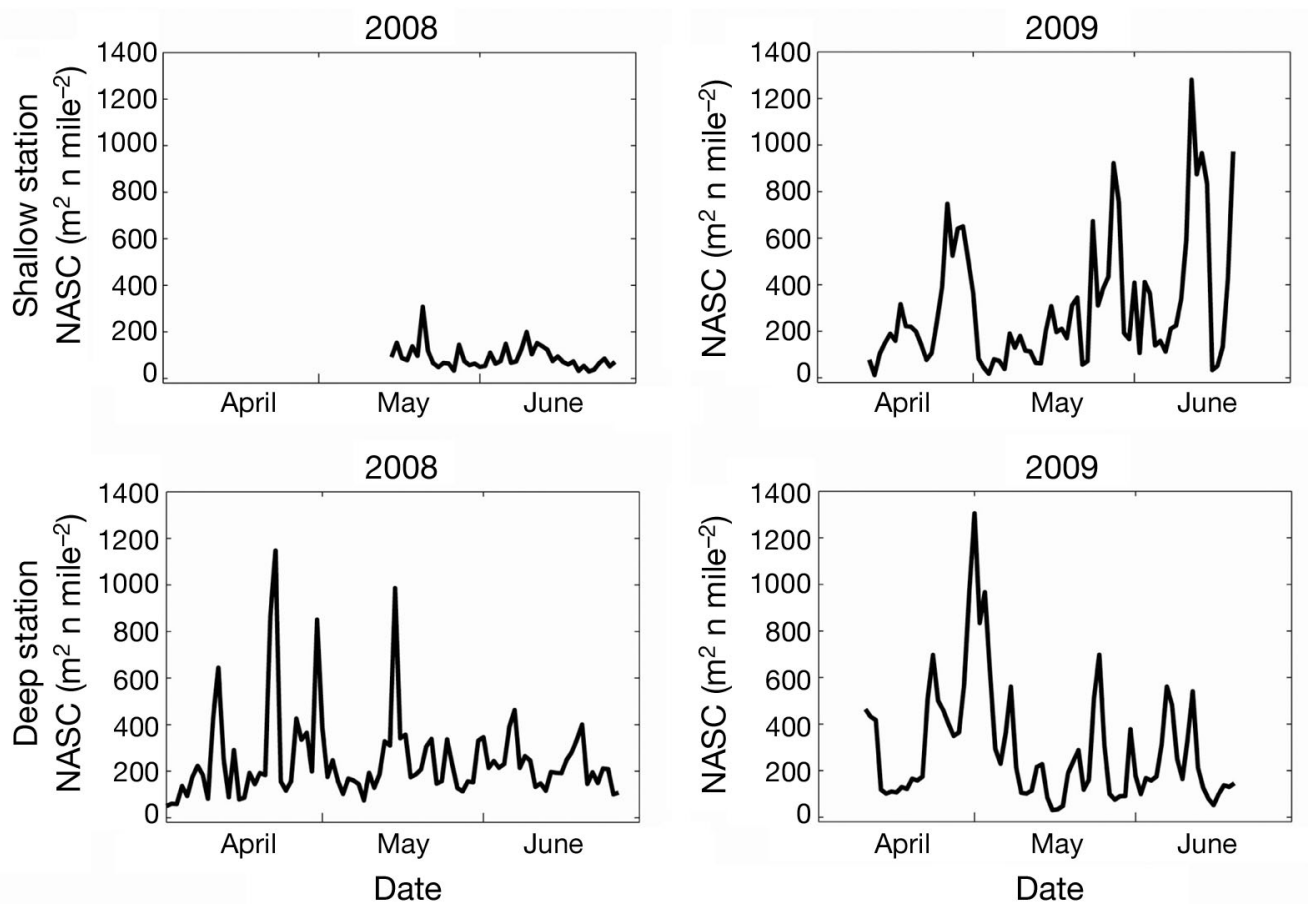

Fig. 6. A proxy for daily zooplankton abundance observed between the surface and $20 \mathrm{~m}$ at the shallow (top) and deep (bottom) mooring stations in 2008 and 2009 identified by the nautical area scattering coefficient (NASC). Note the high-frequency variability, with very large spikes in abundance usually lasting 1 to $3 \mathrm{~d}$. These spikes were usually associated with a reversal in winds and the passage of a temperature or salinity front over the mooring site 
Table 2. Results of Kendall's tau correlation test between ocean conditions and schooling fish abundance observed at bottom-mounted acoustic echosounders at the shallow and deep mooring stations deployed April through June, 2008 and 2009. Significant results are marked with ${ }^{*}$. SST $=$ sea surface temperature, $\mathrm{SSS}=$ sea surface salinity, $\mathrm{CR}=$ Columbia River

\begin{tabular}{|lcc|}
\hline Variable & Correlation & Significance \\
\hline Year & -0.04 & 0.49 \\
Station & -0.10 & 0.06 \\
SST & 0.36 & $<0.001^{*}$ \\
SSS & -1.6 & $<0.001^{*}$ \\
CR flow & 0.24 & $<0.001^{*}$ \\
Upwelling index & 0.23 & 0.05 \\
Zooplankton abundance & -0.3 & 0.5 \\
\hline
\end{tabular}
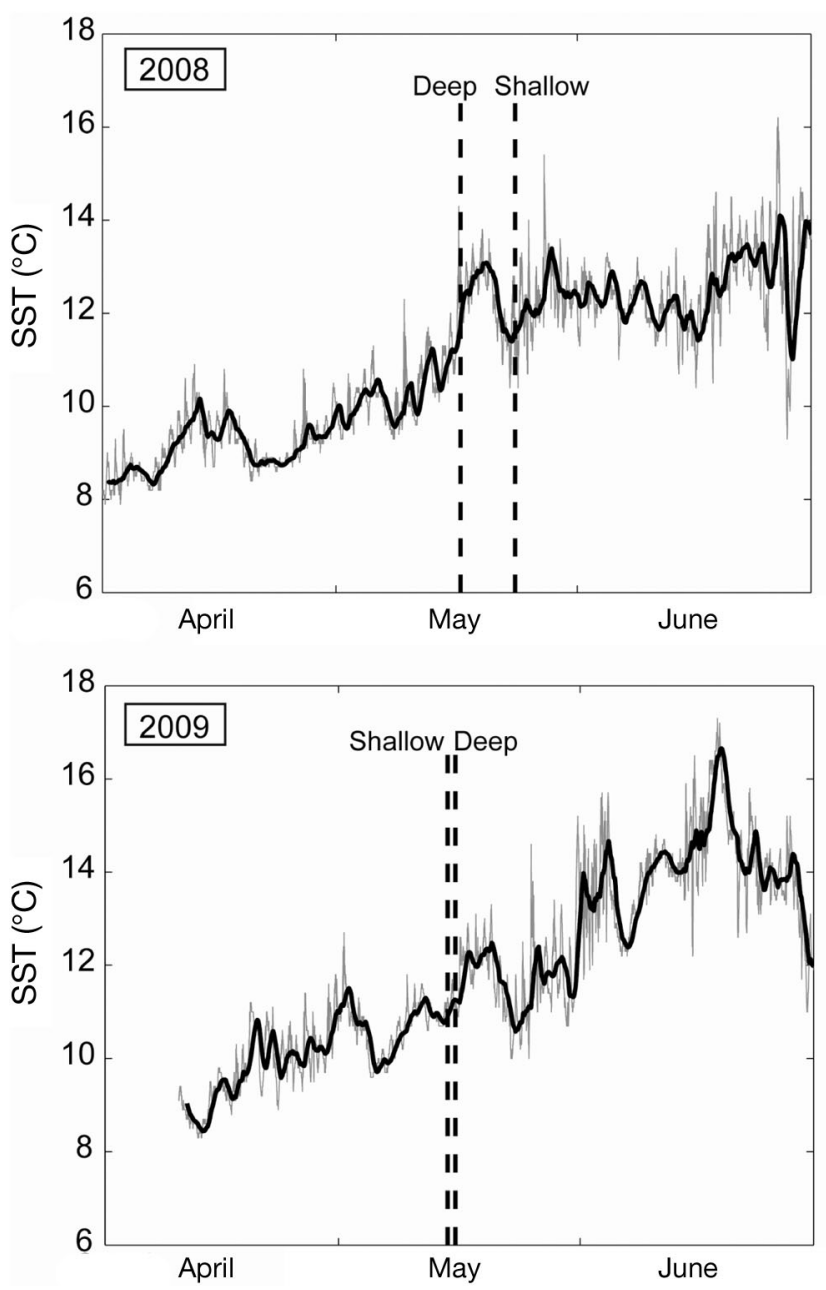

Fig. 7. Sea surface temperature (SST) measured at the Oregon Graduate Institute (OGI) buoy at the deep acoustic mooring station (gray line) and the $24 \mathrm{~h}$ running average smoothed line (black line) in 2008 and 2009. The dates of schooling fish arrival at the shallow and deep acoustic mooring stations are indicated with the dashed lines

\section{Fish species composition}

Net trawl sampling indicated that there were differences in fish species composition by density for each species, both temporally and between sampling stations (Table 3). Trawl sampling nearest the shallow mooring station, CR7, in 2008 and 2009 indicated that smelt Osmeridae spp. were the dominant group present (Table 3) in May and June samples (Fig. 8). However, smelts were absent from samples at the deeper trawl station, CR15. Trawl samples at the deep station were dominated by northern anchovy in May and either Pacific hake Merluccius productus or Pacific sardine Sardinops sagax in June (Fig. 8).

A visual comparison of the acoustic schooling fish abundance with the total fish density from net trawls showed high agreement by the 2 methods in the relative abundance at the overlapping sampling points (Figs. 5 \& 8). However, these trawl samples typically did not resolve the timing of arrival as well as the acoustic time series (Fig. 8).

\section{DISCUSSION}

Continuous observations from bottom-mounted acoustic moorings provided an effective method to identify the timing of movements of schooling fish and zooplankton abundance in the northern California Current. The appearance of acoustic surface schools, a proxy for forage fish, were distinct events at each sampling station and we were able to identify a specific day during each year when forage fish schools appeared and consistently remained for the remainder of the sampling period. A few small periods of school detections were observed prior to that day of arrival. However, these early schools that were not visually or statistically different from other schools were limited to only a few occasions and did not persist over adjacent days, indicating that they were not associated with the arrival of a large portion of the schooling fish population into the study area. The timing of school appearance in the 2 yr were very similar to each other for both the deep station (May 24 in 2008, May 15 in 2009) and the shallow station (May 17 in 2008, May 16 in 2009). We should note that only $2 \mathrm{~d}$ of fish absence preceded the appearance of fish at the shallow station in 2008, since the data record began on May 15. It is not possible to know if forage fish were present before that date, but the brief period of $2 \mathrm{~d}$ with very low abundance followed by a large spike was similar to the pattern observed in 2009.

Schooling fish abundances at both stations determined acoustically were highly linked with sea surface temperature, sea surface salinity, and river flow. The 
shallow station, being in closer proximity to the mouth of the Columbia River, is more strongly influenced by the river plume, and is likely within the plume for the majority of the time during summer upwelling conditions. Therefore, the conditions in the surface layer at the shallow station are dominated by river flows.

Surface trawl sampling was conducted in the region near the mooring stations as part of the NOAA 'Predator Study', which conducts bi-weekly sampling cruises in May and June every year. Although the trawl stations routinely sampled in this program are spatially offset from the acoustic moorings, the 2 stations nearest the moorings and occupying similar water depths as the mooring stations were used to provide species identification representing the species present in the acoustics data. These trawl samples indicated that there were differences in the dominant species of forage fish between the 2 stations. Trawl catches conducted at the shallow station were dominated by whitebait smelt Allosmerus elongatus and northern anchovy Engraulis mordax, while trawls nearest the deep station were dominated by Pacific sardine Sardinops sagax and Pacific hake Merluccius productus (Table 3). These trawl samples also suggested that there were temporal shifts in species composition with sardines becoming more abundant over anchovies in June at the deep station. The dates that were defined as the appearance of forage fish schools in the acoustic data record likely correspond to the timing of the earliest migrating species, which would tend to be anchovy and whitebait smelt. Another important point to note is that the trawl sampling dates were not exactly the same in both years due to weather, logistics, etc. This difference in sampling dates could have lead to different monthly proportions of species when comparing the $2 \mathrm{yr}$, especially given that the results presented here show that day-to-day variability to total forage fish can be very high.

Relative forage fish abundances determined acoustically were generally in agreement with total fish density determined from trawl surveys (Figs. $5 \& 8$ ). For each station in each year, there were 2 to 4 trawl sample points available during the acoustic time series, which resolved a similar pattern in total fish abundance. However, it was clear that these trawl points often missed fluctuations that occurred between sampling dates, which was especially the case at the deep station in 2009 when schooling fish abundances were relatively low on the trawl sampling dates of June 8 and June 22, but remained much higher for the $2 \mathrm{wk}$ period in between sampling dates. Further, even though a trawl was conducted on May 26 at the deep station in 2008, near the timing of schooling fish arrival, the total density from trawl sampling did not indicate high abundance until the next trawl on

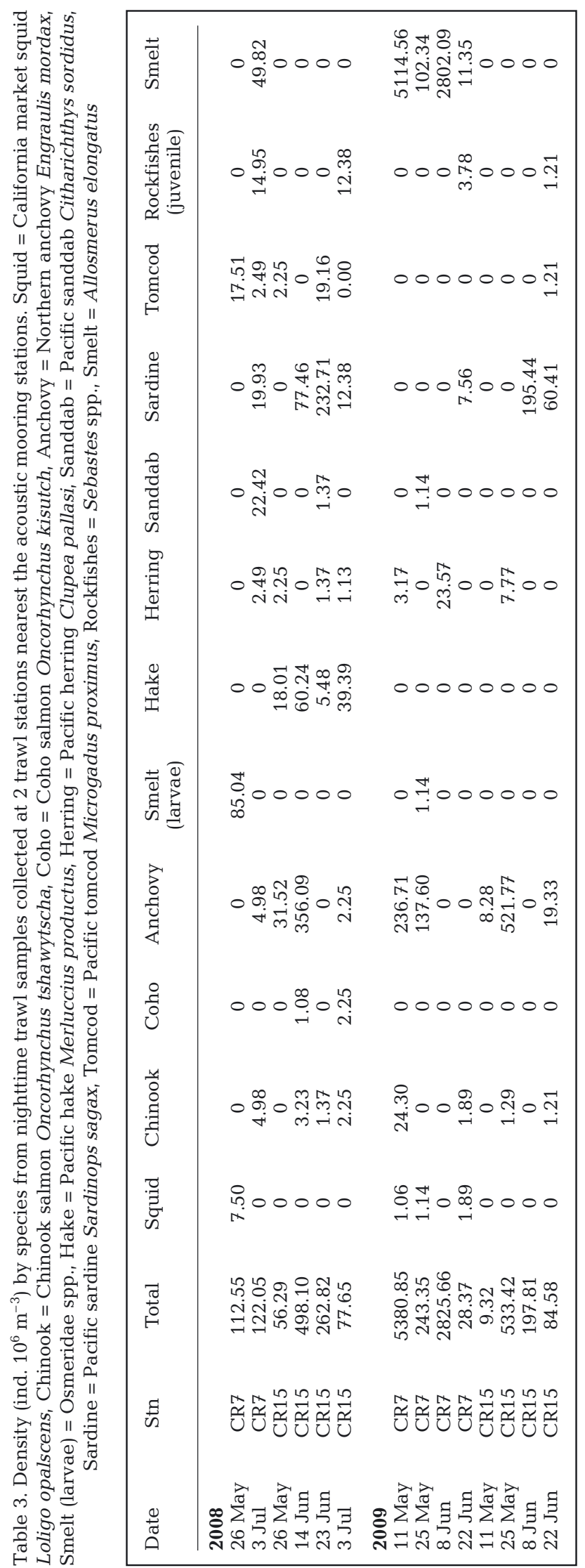


June 14. These comparisons indicate that routine net sampling, even with the high bi-weekly frequency, did not resolve the short-term variability of forage fish populations at these sampling stations, or identify the distinct timing when schools appeared. Additionally, weather conditions near the Columbia River plume often limit ship-board sampling, especially in April and May, making it even more difficult to capture the timing of forage fish arrival. The stationary acoustic moorings in the study demonstrates the utility of adding moored acoustics to net sampling programs to identify daily fluctuations of acoustic backscatter abundance representing schooling fish and mesozooplankton. Future sampling designs for studies involving the timing of ecosystem events in regions with seasonal presence of forage fish would likely also benefit from the incorporation of continuous sampling platforms, such as acoustic moorings, to identify fish and zooplankton variability.

The timing of schooling fish appearance into the Columbia River plume region is likely driven by fish responding to a combination of factors and selecting their preferred physical and prey environments. Winddriven coastal upwelling characteristics during the

\begin{tabular}{|llll|}
\hline California market squid & Northern anchovy & Pacific herring & Pacific tomcod \\
Chinook salmon & Osmeridae (larvae) & Pacific sanddab & $\mathbf{D}$ Whitebait smelt \\
Coho salmon & Pacific hake & Pacific sardine & \\
\hline
\end{tabular}
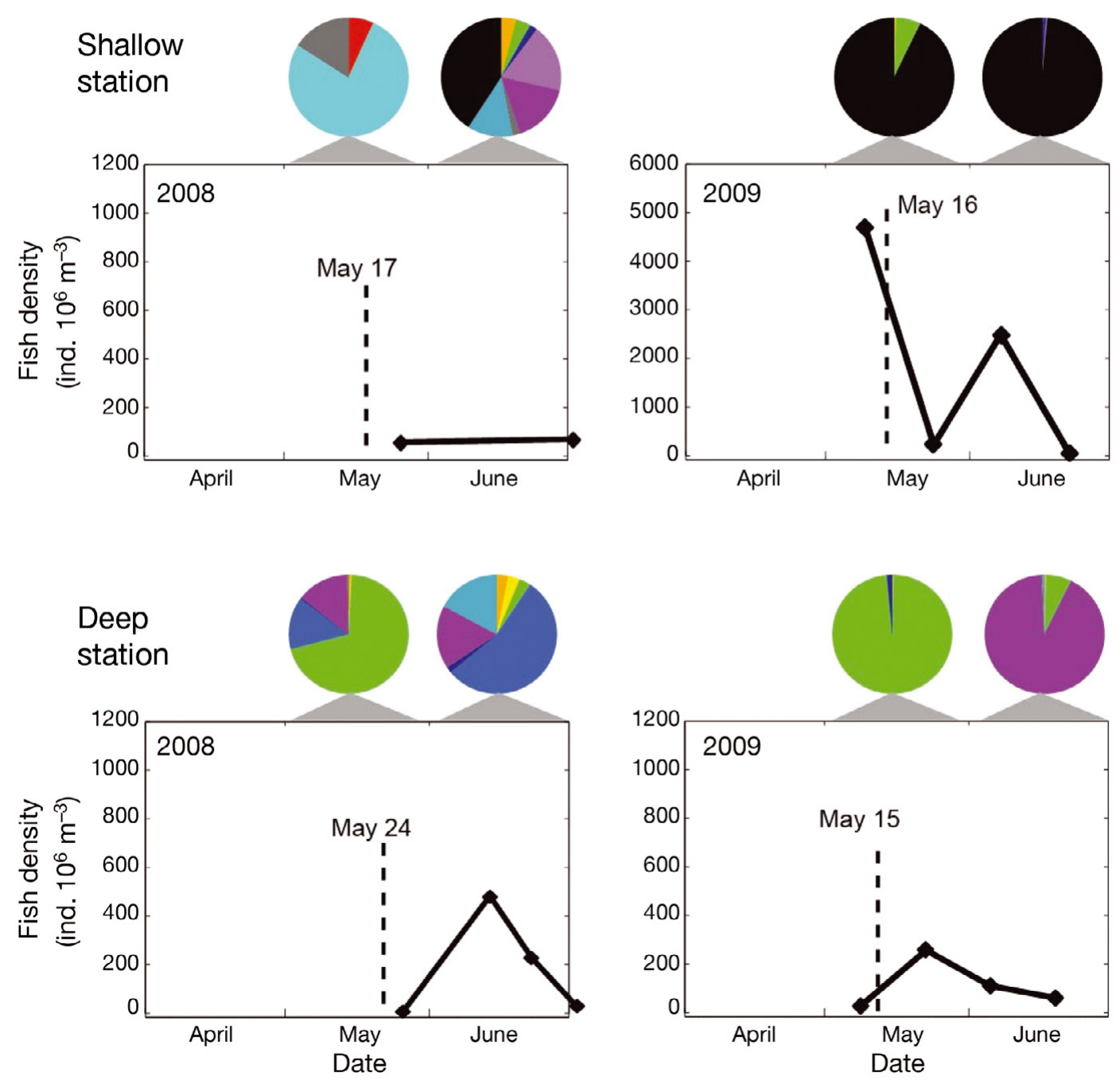

Fig. 8. Total fish density (ind. $10^{6} \mathrm{~m}^{-3}$ ) at trawl stations ( 2 and $15 \mathrm{~km}$ from the shallow [top] and deep [bottom] acoustic stations, respectively). $Y$-axes were scaled to best match acoustic samples for relative comparisons, and the date of forage fish arrival based on acoustic mooring data are indicated by the dashed lines for reference. Pie charts above each plot detail the species composition for each month. Scientific names of species are available in Table 3 
2 sampling years were slightly different in the timing of the spring transition, but they were much more similar to each other when compared with the previous 5 yr (ranging from March 15 in 2007 to May 24 in 2005) (Fig. 3). The cumulative strength of upwelling from the spring transition was also very similar over these 2 years relative to other previous years (Fig. 3). We speculate that the similar timing of forage fish appearance during these 2 years may have been linked with the similarity in the timing and strength of physical upwelling characteristics experienced during these years. More sampling on the timing of school appearance over a number of years under variable upwelling conditions would be needed to further test how these patterns are influenced by variability in the timing of seasonal upwelling.

Variability in the timing and strength of upwelling between years has previously been shown to have extensive impacts on the ecosystem with cascading effects observed throughout the entire food web. The anomalously late upwelling in 2005 ( 50 d later than the average) was associated with warmer than average sea surface temperatures throughout the northern California Current System (Kosro et al. 2006, Pierce et al. 2006, Schwing et al. 2006, Barth et al. 2007). A shift in the normal spawning distribution of forage fish species was observed, with spawning activity occurring farther north and onshore than typical (Brodeur et al. 2006). California sea lions Zalophus californianus altered their foraging behavior in 2005 as they traveled farther during foraging trips to utilize offshore species of forage fish (Weise et al. 2006). The planktivorous auklet Ptychoramphus aleuticus had almost a complete reproductive failure off central California and southern British Columbia in 2005 due to a lack of their euphausiid prey (Sydeman et al. 2006). It appears that the ecosystem consequences of delayed upwelling strongly influence the phenology and distribution of forage fish.

Forage fish distributions are strongly linked to ocean temperatures in the California Current (Lluch-Belda et al. 1992) as well as in other coastal upwelling systems (Castillo et al. 1996). The appearance of forage fish schools at the deep and shallow mooring sites occurred shortly after a sharp rise in sea surface temperature to about $11^{\circ} \mathrm{C}$. This pattern is consistent with other observations linking sardine and anchovy spawning distributions to specific sea surface temperatures (LluchBelda et al. 1991).

The short term variability of abundance observed at the stationary sampling locations is related to the spatial distributions of fish as they respond to changing ocean conditions and select preferred habits. Combining the information from oceanographic sensors with information on the variability in schooling fish abun- dance observed at the mooring stations provides insight into what factors forage fish schools were selecting for. We found no significant correlation between forage fish and mesozooplankton abundance. The abundance of mesozooplankton in the surface layer (0-20 $\mathrm{m}$ from the surface) at the 2 sampling stations was dominated by high frequency variability, with strong peaks usually lasting between 1 and $3 \mathrm{~d}$, likely associated with the passage of the Columbia River plume front due to the interaction of winds and river flow.

This region is strongly influenced by the low salinity, high temperature Columbia River plume (Hickey et al. 2005). Currents and tides determine the position and extent of the plume and drive variability in the position of river fronts. Our observations of large spikes in zooplankton abundance are consistent with the passage of river fronts that has been observed in other studies showing aggregation of zooplankton (Morgan et al. 2005, Peterson \& Peterson 2008, Peterson \& Peterson 2009). Zooplankton aggregations at the river front were also observed closer to the surface (within $10 \mathrm{~m}$ of the surface) than in regions without fronts (within $25 \mathrm{~m}$ of the surface) (Peterson \& Peterson 2008), which may be important in attracting or retaining larger predators.

High variability of zooplankton abundance due to variability in the position of the river front may be a possible explanation for the lack of a consistent correlation between forage fish and mesozooplankton abundance sampled during this study. The mesozooplankton community sampled by the acoustic moorings also represented only a portion of the total prey items available for the diet of forage fish. Forage fish feed opportunistically on a variety of plankton groups, and may switch between filter feeding on phytoplankton and particle feeding on zooplankton depending on availability of prey items (Garrido et al. 2007, 2008). Forage fish abundance has been shown to reflect changes in zooplankton concentrations on an interannual scale, but lag zooplankton abundance by 1 yr (Emmett et al. 2006). Garrido et al. (2008) also showed a correlation between phytoplankton contribution in sardine diets and satellite-derived chlorophyll concentration. Stomach content analysis of Pacific sardines Sardinops sagax collected during day and night sampling in the Columbia River plume region were conducted by Emmett et al. (2005). In that study, all sardine stomachs analyzed were full, indicating that prey might not be limiting to individual fish during this transition period. Further, sardine stomach content was poorly related with neuston biovolume, and phytoplankton composition did not reflect the ambient chlorophyll a concentrations, which may be further evidence that forage fish in this region select their 
habitat based primarily on physical conditions because ambient prey concentrations during spring are generally not limiting.

The distribution of forage fishes in the northern California Current is strongly seasonal. Pacific sardines appear to migrate from their early spring spawning grounds off California to Oregon, Washington, and British Columbia, Canada to forage during summer months (Clark \& Janssen 1945). However, anchovy, smelts, and herring do not migrate to California; they over-winter by moving offshore to deep water habitats (Hernandez-Vazquez 1994). Regardless of their wintering locations, the seasonal presence of forage fish in the coastal region has important ecosystem effects on many groups that depend on them as predators, prey, or co-prey. For example, a recent study found that the timing of salmon smolt arrival to the ocean may determine their marine survival (Scheuerell et al. 2009). We suspect that forage fish presence plays a significant role in early marine survival of juvenile salmon, by acting as competitors or by serving as alternative prey to mutual predators (Pearcy 1992, Beamish \& Mahnken 2001, Emmett et al. 2006). The outmigration of juvenile salmon from the Columbia River takes place in spring (April-June), during our study period for coho salmon Oncorhynchus kisutch, yearling Chinook salmon O. tshawytscha, sockeye salmon O. gorbuscha, chum salmon O. keta, and steelhead trout, O. mykiss. Columbia River salmon smolt outmigration timing may be regulated by timing the release of hatchery smolts and controlling the river flow through dams. Understanding the factors controlling the timing of forage fish presence in the Columbia River plume could be used to increase the effectiveness of salmon restoration and enhancement management efforts. This may be particularly important in the face of anticipated anthropogenic changes in global temperatures, as the timing and strength of seasonal upwelling are also expected to change. These changes are expected to lead to shifts in the timing and strength of coastal wind-driven upwelling, leading to disruptions in the overlap of predator-prey relationships in these regions ('match-mismatch hypothesis') (Cushing 1990), and a number of recent studies have demonstrated the ecological effects of these phenological shifts (Sydeman \& Bograd 2009).

The results of this study have significant implications for the use of acoustics in ecosystem-based management efforts. Bottom-mounted, upward-oriented moored echosounders such as those used in this study can provide continuous time series data on total fish density at much higher resolution than can be obtained from ship-board acoustic and trawl surveys, and can avoid biases associated with ship avoidance behaviors. Although this study distinguished between major groups of organisms (schooling fish and mesozooplankton) based on their visual and morphometric characteristics, future studies could be improved by replacing the single frequency echosounder mooring with the increasingly available multi-frequency, splitbeam echosounders, which can provide information on target strength and improved target identification. The use of additional frequencies in combination with oceanographic buoy data could also improve the ability to include greater trophic levels, a goal for endto-end ecosystem models and studying predator-prey interactions (Koslow 2009).

Forage fish represent a critical link in coastal upwelling ecosystems and their temporal and spatial distribution patterns are important ecosystem variables. Currently, Chinook salmon Oncorhynchus tshawytscha and coho salmon $O$. kisutch populations are supplemented with the addition of hatchery-reared smolts that are released into the Columbia River prior to entry into the ocean. This study shows that if forage fish populations play a role in determining marine juvenile salmon survival, then the timing of ocean entry by juvenile salmon is critical due to the abrupt appearance of forage fishes observed here. The ocean conditions that juvenile salmon inhabit one day may be very different than the conditions that they face the following day. The timing of forage fish appearance was poorly related to zooplankton prey conditions, but was much more strongly related to abiotic conditions (i.e. temperature, salinity, and upwelling index). These variables are monitored in this region by a number of sources that have data available to managers in near real-time (e.g. NDCB, OGI). Furthermore, the use of near real-time biological indices of forage fish abundance off the Columbia River through the incorporation of bio-acoustic instrumentation could improve marine juvenile salmon survival by optimizing ocean entry timing so that salmon would enter the ocean when forage fish was abundant and environmental conditions are best.

Acknowledgements. C. Waluk, P. Bentley, A. Claiborne, and M. Litz provided field assistance for this project. R. Collier and W. Waldorf provided equipment used during mooring deployments. We thank C. Seaton, M. Wilkin, A. Baptista and the Center for Coastal Margin Observation and Prediction for providing OGI buoy data. This work was funded by the Army Corps of Engineers.

\section{LITERATURE CITED}

Anderson DW, Gress F, Mais KF (1982) Brown pelicans: influence of food supply on reproduction. Oikos 39:23-31

Anderson S, Roby D, Lyons D, Collis K (2007) Relationship of Caspian tern foraging ecology to nesting success in the Columbia River estuary, Oregon, USA. Estuar Coast Shelf Sci 73:447-456 
Azzali M, Buracchi G, Conti S, Gambetti S, Luna M (1985) Relationship between the forms of pelagic fish distribution and nycthemeral periods. A tentative model of behaviour. Oebalia 11:471-488

Bakun A (1973) A daily and weekly upwelling index, west coast of North America. NOAA Tech Rep NMFS SSRF671. Seattle, WA

Barange M (1994) Acoustic identification, classification and structure of biological patchiness on the edge of the Agulhas Bank and its relation to frontal features. S Afr J Mar Sci 14:333-347

Barth JA, Menge BA, Lubchenco J, Chan F and others (2007) Delayed upwelling alters nearshore coastal ocean ecosystems in the northern California current. Proc Natl Acad Sci USA 104: 3719-3724

Baumgartner T, Soutar A, Ferreira-Bartrina V (1992) Reconstruction of the history of Pacific sardine and northern anchovy populations over the past two millennia from sediments of the Santa Barbara Basin, California. Cal Coop Ocean Fish Invest Rep 33:24-40

Beamish R, Mahnken C (2001) A critical size and period hypothesis to explain natural regulation of salmon abundance and the linkage to climate and climate change. Prog Oceanogr 49:423-437

Bograd S, Schroeder I, Sarkar N, Qiu X, Sydeman W, Schwing F (2009) Phenology of coastal upwelling in the California Current. Geophys Res Lett 36:L01602 doi:10.1029/2008 GL035933

Bottom D, Simenstad C, Baptista A, Jay D and others (2001) Salmon at river's end: the role of the estuary in the decline and recovery of Columbia River salmon. NOAA, NWFSC, Seattle, WA

Breder CM (1976) Fish schools as operational structures. Fish Bull 74:471-502

Brodeur RD, Pearcy WG (1992) Effects of environmental variability on trophic interactions and food web structure in a pelagic upwelling ecosystem. Mar Ecol Prog Ser 84: 101-119

> Brodeur RD, Pearcy WG, Ralston S (2003) Abundance and distribution patterns of nekton and micronekton in the northern California current transition zone. J Oceanogr 59:515-535

Brodeur RD, Fisher JP, Emmett RL, Morgan CA, Casillas E (2005) Species composition and community structure of pelagic nekton off Oregon and Washington under variable oceanographic conditions. Mar Ecol Prog Ser 298:41-57

Brodeur R, Ralston S, Emmett R, Trudel M, Auth T, Phillips A (2006) Anomalous pelagic nekton abundance, distribution, and apparent recruitment in the northern California Current in 2004 and 2005. Geophys Res Lett 33:L22S08 doi:10.1029/2006GLO26614

> Cardinale M, Casini M, Arrhenius F, Håkansson N (2003) Diel spatial distribution and feeding activity of herring Clupea harengus and sprat Sprattus sprattus in the Baltic Sea. Aquat Living Resour 16:283-292

Castillo J, Barbieri M, Gonzalez A (1996) Relationships between sea surface temperature, salinity, and pelagic fish distribution off northern Chile. ICES J Mar Sci 53: 139-146

Clark F, Janssen J (1945) Movements and abundance of the sardine as measured by tag returns. Fish Bull 61:1-90

> Cury P, Bakun A, Crawford RJM, Jarre A, Quinones RA, Shannon LJ, Verheye HM (2000) Small pelagics in upwelling systems: patterns of interaction and structural changes in 'wasp-waist' ecosystems. ICES J Mar Sci 57: 603-618

Cushing D (1990) Plankton production and year-class strength in fish populations: an update of the match/ mismatch hypothesis. Adv Mar Biol 26:249-293

Emmett RL, Sampson DB (2007) The relationships between predatory fish, forage fishes, and juvenile salmonid marine survival off the Columbia River: a simple trophic model analysis. Cal Coop Ocean Fish Invest Rep 48: 92-105

Emmett RL, Brodeur RD, Miller TW, Pool SS, Bentley PJ, Krutzikowsky GK, McCrae J (2005) Pacific sardine Sardinops sagax abundance, distribution and ecological relationships in the Pacific Northwest. Cal Coop Ocean Fish Invest Rep 46:122-143

Emmett RL, Krutzikowsky GK, Bentley P (2006) Abundance and distribution of pelagic piscivorous fishes in the Columbia River plume during spring/early summer 1998-2003: relationship to oceanographic conditions, forage fishes, and juvenile salmonids. Prog Oceanogr 68: $1-26$

Fréon P, Misund OA (1999) Dynamics of pelagic fish distribution and behaviour: effects on fisheries and stock assessment. Blackwell Fishing News Books, London

Fréon P, Gerlotto F, Soria M (1996) Diel variability of school structure with special reference to transition periods. ICES J Mar Sci 53:459-464

Garrido S, Marcalo A, Zwolinski J, van der Lingen CD (2007) Laboratory investigations on the effect of prey size and concentration on the feeding behaviour of Sardina pilchardus. Mar Ecol Prog Ser 330:189-199

Garrido S, Ben-Hamadou R, Oliveira PB, Cunha ME, Chicharo MA, van der Lingen CD (2008) Diet and feeding intensity of sardine Sardina pilchardus: correlation with satellite-derived chlorophyll data. Mar Ecol Prog Ser 354: 245-256

> Hedd A, Bertram DF, Ryder JL, Jones IL (2006) Effects of interdecadal climate variability on marine trophic interactions: rhinoceros auklets and their fish prey. Mar Ecol Prog Ser 309:263-278

Hernandez-Vazquez S (1994) Distribution of eggs and larvae from sardine and anchovy off California and Baja California, 1951-1989. Cal Coop Ocean Fish Invest Rep 35: 94-107

Hickey B, Geier S, Kachel N, MacFadyen A (2005) A bi-directional river plume: The Columbia in summer. Cont Shelf Res 25:1631-1656

Holt CA, Mantua N (2009) Defining spring transition: regional indices for the California Current System. Mar Ecol Prog Ser 393:285-299

> Hsieh C, Reiss CS, Hunter JR, Beddington JR, May RM, Sugihara G (2006) Fishing elevates variability in the abundance of exploited species. Nature 443:859-862

Kaltenberg AM, Benoit-Bird KJ (2009) Diel behavior of sardine and anchovy schools in the California Current System. Mar Ecol Prog Ser 394:247-262

> Kieser R, Mulligan TJ, Richards LJ, Leaman BM (1993) Bias correction of rockfish school cross section widths from digitized echo sounder data. Can J Fish Aquat Sci 50: 1801-1811

Koslow JA (2009) The role of acoustics in ecosystem-based fishery management. ICES J Mar Sci 66:966-973

Kosro PM, Peterson WT, Hickey BM, Shearman RK, Pierce SD (2006) Physical versus biological spring transition: 2005. Geophys Res Lett 33:L22S03 doi:10.1029/2006GL027072

Lamb J, Peterson WT (2005) Ecological zonation of zooplankton in the COAST study region off central Oregon in June and August 2001 with consideration of retention mechanisms. J Geophys Res 110:C10S15 doi:10.1029/2004JC00 2520 
Lasker R (1970) Utilization of zooplankton energy by a Pacific sardine population in the California Current, In: Steele JH (ed) Marine Food Chains. Oliver \& Boyd, Edinburgh, p 265-284

Lluch-Belda D, Lluch-Cota DB, Hernandez-Vazquez S, Salinas-Zavala CA, Schwartzlose RA (1991) Sardine and anchovy spawning as related to temperature and upwelling in the California Current System. Cal Coop Ocean Fish Invest Rep 32:105-111

Lluch-Belda D, Schwartzlose RA, Serra R, Parrish R, Kawasaki T, Hedgecock D, Crawford RJM (1992) Sardine and anchovy regime fluctuations of abundance in four regions of the world oceans: a workshop report. Fish Oceanogr 1:339-347

Macleod K, Fairbairns R, Gill A, Fairbairns B, Gordon J, BlairMyers C, Parsons ECM (2004) Seasonal distribution of minke whales Balaenoptera acutorostrata in relation to physiography and prey off the Isle of Mull, Scotland. Mar Ecol Prog Ser 277:263-274

Morgan CA, De Robertis A, Zabel RW (2005) Columbia River plume fronts. I. Hydrography, zooplankton distribution, and community composition. Mar Ecol Prog Ser 299:19-31

Pearcy WG (1992) Ocean ecology of North Pacific salmonids. University of Washington Press, Seattle, WA

Peterson WT (1998) Life cycle strategies of copepods in coastal upwelling zones. J Mar Syst 15:313-326

Peterson JO, Peterson WT (2008) Influence of the Columbia River plume (USA) on the vertical and horizontal distribution of mesozooplankton over the Washington and Oregon shelf. ICES J Mar Sci 65:477-483

Peterson JO, Peterson WT (2009) Influence of the Columbia River plume on cross-shelf transport of zooplankton. J Geophys Res 114:C00B10 doi:10.1029/2008JC004965

Pierce SD, Barth JA, Thomas RE, Fleischer GW (2006) Anomalously warm July 2005 in the northern California Current: historical context and the significance of cumulative wind stress. Geophys Res Lett 33:L22S04 doi:10.1029/ 2006GL027149

Robinson CLK (2000) The consumption of euphausiids by the pelagic fish community off southwestern Vancouver Island, British Columbia. J Plankton Res 22:1649-1662

Rykaczewski RR, Checkley DM (2008) Influence of ocean winds on the pelagic ecosystem in upwelling regions. Proc Natl Acad Sci USA 105:1965-1970

Safina C, Burger J (1988) Prey dynamics and the breeding phenology of common terns Sterna hirundo. Auk 105: 720-726

Editorial responsibility: Hans Heinrich Janssen, Oldendorf/Luhe, Germany
Scheuerell MD, Zable RW, Sandford BP (2009) Relating juvenile migration timing and survival to adulthood in two species of threatened Pacific salmon. J Appl Ecol 46: 983-990

Schwing FB, O'Farrell M, Steger J, Baltz K (1996) Coastal upwelling indices, west coast of North America 1946-1995. NOAA Tech Memo NOAA-TM-NMFSSWFC231

Schwing FB, Bond NA, Bograd SJ, Mitchell T, Alexander MA, Mantua N (2006) Delayed coastal upwelling along the US West Coast in 2005: a historical perspective. Geophys Res Lett 33:L22S01. doi:10.1029/2006GL02911

Similä T, Holst JC, Christensen I (1996) Occurrence and diet of killer whales in northern Norway: seasonal patterns relative to the distribution and abundance of Norwegian spring-spawning herring. Can J Fish Aquat Sci 53: 769-779

Sinclair EH, Zeppelin TK (2002) Seasonal and spatial differences in diet in the western stock of steller sea lions Eumetopias jubatus. J Mammal 83:973-990

Sydeman WJ, Bograd SJ (2009) Marine ecosystems, climate and phenology: introduction. Mar Ecol Prog Ser 393: 185-188

Sydeman WJ, Bradley RW, Warzybok P, Abraham CL and others (2006) Planktivorous auklet Ptychoramphus aleuticus responses to ocean climate, 2005: unusual atmospheric blocking. Geophys Res Lett 33:L22S09 doi:10.1029/2006 GL026736

Urick RJ (1983) Principles of underwater sound. McGraw Hill, New York, NY

Weise MJ, Costa DP, Kudela RM (2006) Movement and diving behavior of male California sea lion Zalophus californianus during anomalous oceanographic conditions of 2005 compared to those of 2004. Geophys Res Lett 33:L22S10 doi:10.1029/2006GL027113

> Womble JN, Sigler MF (2006) Seasonal availability of abundant, energy-rich prey influences the abundance and diet of a marine predator, the Steller sea lion Eumetopias jubatus. Mar Ecol Prog Ser 325:281-293

Womble JN, Willson MF, Sigler MF, Kelly BP, VanBlaricom GR (2005) Distribution of Steller sea lions Eumetopias jubatus in relation to spring-spawning fish in SE Alaska. Mar Ecol Prog Ser 294:271-282

Woodson CB, Webster DR, Weissburg MJ, Yen J (2005) Response of copepods to physical gradients associated with structure in the ocean. Limnol Oceanogr 50:1552- 1564

Submitted: January 13, 2010; Accepted: September 28, 2010 Proofs received from author(s): November 23, 2010 